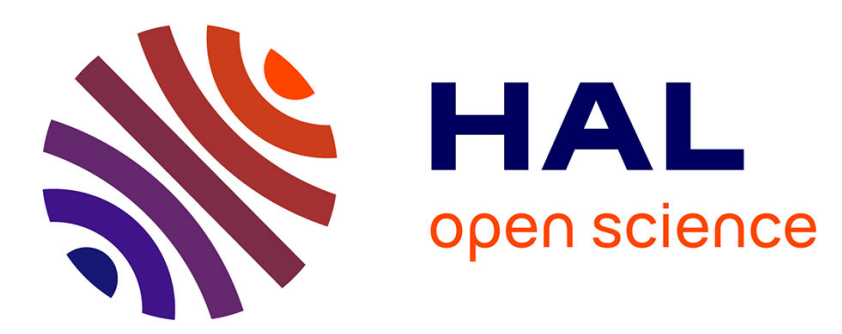

\title{
Variation of wood color parameters of Tectona grandis and its relationship with physical environmental factors
} Moya, Calvo-Alvarado

\section{To cite this version:}

Moya, Calvo-Alvarado. Variation of wood color parameters of Tectona grandis and its relationship with physical environmental factors. Annals of Forest Science, 2012, 69 (8), pp.947-959. 10.1007/s13595012-0217-0 . hal-00930867

\section{HAL Id: hal-00930867 https://hal.science/hal-00930867}

Submitted on 1 Jan 2012

HAL is a multi-disciplinary open access archive for the deposit and dissemination of scientific research documents, whether they are published or not. The documents may come from teaching and research institutions in France or abroad, or from public or private research centers.
L'archive ouverte pluridisciplinaire HAL, est destinée au dépôt et à la diffusion de documents scientifiques de niveau recherche, publiés ou non, émanant des établissements d'enseignement et de recherche français ou étrangers, des laboratoires publics ou privés. 


\title{
Variation of wood color parameters of Tectona grandis and its relationship with physical environmental factors
}

\author{
Róger Moya $\cdot$ Julio Calvo-Alvarado
}

Received: 25 January 2012 / Accepted: 3 May 2012 / Published online: 17 May 2012

(C) INRA / Springer-Verlag France 2012

\begin{abstract}
- Context Teak's wood color is considered an important attribute in the marketing phase and it has been influenced by environmental setting, stand conditions and management, plant genetic source, and age. However, there is a lack of understanding about how the environmental factors might affect the teak's wood color planted in short-rotation forest plantations.

- Aims The aim of this study is to understand the relationship, gathered from generated information, between edaphic and climatic variables and their effects in the wood color variation of Tectona grandis from trees in forest plantations. - Methods Twenty-two plots were grouped in five cluster sites that shared similar climatic and soil conditions. Data about soil's physical-chemical properties and climatic variables were collected and analyzed. Representative trees were harvested next to each plot in order to obtain a wood sample per tree at a diameter breast height. Wood color
\end{abstract}

Handling Editor: Jean-Michel Leban

Contribution of the co-authors Moya contributed with designing the experiment, sampling of tree, determining of wood, running the data analysis, and coordinating the research project.

Calvo-Alvarado contributed with designing the experiment, writing the paper, and running the data analysis.

R. Moya $(\varangle) \cdot J$. Calvo-Alvarado

Escuela de Ingeniería Forestal,

Instituto Tecnológico de Costa Rica,

Apartado, 159-7050 Cartago, Costa Rica

e-mail: rmoya@itcr.ac.cr

J. Calvo-Alvarado

e-mail: jucalvo@itcr.ac.cr was measured using standardized CIELab's chromaticity system.

- Results After comparing the wood change color index $\left(\Delta E^{*}\right)$ in the five studied clusters, it was found that heartwood produced from drier and fertile sites had more yellowish-brown color. The heartwood $b^{*}$ color index resulted with significant correlations $(R>0.5, P<0.05)$ among nine climatic and eight edaphic variables.

- Conclusion It was concluded that climatic variables should be considered as the first-order causal variables to explain wood color variation. Hence, darker $b^{*}$ wood color was associated with dry climates; also, with deeper and fertile sites.

Keywords Wood color · CIELab's color system · Wood properties $\cdot$ Tree environmental factors

\section{Introduction}

Wood color differs widely among species, between different trees of same species and within a tree (Nishino et al. 1998, Liu et al. 2005). The color variation between trees from the same species is done by several factors such as: tree age, soil composition, tree growth, and location of boards inside the tree (Nishino et al. 1998, Liu et al. 2005). Wood color is an important deciding industrial feature for many uses like furniture and decorative veneers. Hence, wood color is considered as an important attribute in the marketing phase. So, the desired industrial goal is to improve the wood's uniform color. This is so because if the wood color uniformity is improved customers may be willing to pay higher prices (Vetter et al. 1990; Mazet and Janin 1990). For this 
reason, it is necessary to saw log from plantation with low variability.

The specie Tectona grandis Linn F. (Teak) has been widely planted in all tropical regions including Latin America, Asia, Africa, and Oceania, covering approximately 6 million hectares (FAO 2006). Teak wood is well-known in the international market for its durability, and excellent mechanical and exceptional aesthetical properties (Tewari 1999). Teak is a premier hardwood valued for its golden yellow to brown color (Thulasidas et al. 2006). In Costa Rica, teak plantations have been extensively planted for fast growth and high timber productivity; and usually trees are harvested in short-rotation periods of less than 15 years (Moya and Pérez 2007; Bermejo et al. 2004; Perez and Kanninen 2005). The high demand for incorporating new planting sites in Costa Rica has led to the establishment of forest plantations on marginal agricultural lands (steep slopes or acid infertile soils) resulting in some cases in slow growth and high management costs because of intensive management practices (Alvarado 2006; Pal and Husen 2003; Webb et al. 2006). One important constraint about teak wood produced from Costa Rica's forest plantations is that its color is usually light brown with a large variation, leading to the nickname of "baby teak wood" (Moya and Pérez 2007; Moya and Berrocal 2010). As indicated by Thulasidas et al. (2006), wood from short-rotation trees' plantations, generally, have a lower price in the timber market because the wood is considered inferior in its quality attributes such as: color, density, natural durability, and mechanical properties.

There are several colorimetric systems for measuring wood color parameters; one of the most accurate and commonly used methods is the CIELab's color system (Gierlinger et al. 2004). This system has been used to evaluate wood color in various applications for example: (1) softwoods and hardwoods (Sotelo-Montes et al. 2008); (2) variation among tree species (Nishino et al. 1998; Nishino et al. 2000); (3) variation according to plant genetic sources (Sotelo-Montes et al. 2008); (4) effects of drying (Möttönen et al. 2002), chemical preservation treatments (Kamdem and Grelier 2005), and wood thermal treatment (Johansson and Morén 2006).

According to Rigatto et al. (2004) and Zobel and Van Buijtenen (1989), wood physical and chemical properties can vary with environmental factors. For example, low wood density may occur on sites with favorable soil properties for stand growth, resulting in low quality of wood for structural uses (Cutter et al. 2004). Some studies have demonstrated that wood color also is influenced by many factors such as: environmental setting, stand conditions and management, plant genetic source, tree age, and extractives content (Phelps et al. 1983; Rink and Phelps 1989; Saranpää 2003, Gierlinger et al. 2004). More specifically for teak, Thulasidas et al. (2006) and Bhat et al. (2005) reported that light brown color and low decay resistance were related to wetter sites and with trees growing in home gardens in Kerala, India. Also, Kokutse et al. (2006) showed that heartwood was lightest nearest the pith with darkness $\left(L^{*}\right)$ and redness $\left(a^{*}\right)$ increasing towards the heartwood's outer; and that low decay durability was related to an increase in wood lightness $\left(L^{*}\right)$. Bhat (1999) identified two broad wood color groups according to contrasting geographic regions in Asia: (1) uniform golden yellow to brown typical of the tropical wet climates along the coasts, and (2) a darker color commonly found in the tropical dry climates of central areas.

In Central America, a strong relationship has been demonstrated between teak timber production and soil physical and chemical properties. Alvarado and Fallas (2004) and Ugalde et al. (2005) pointed out that there was a systematic reduction of average stand growth as soil falls below $\mathrm{pH}$ 6, with an optimum growth rate taking place when calcium concentration is over $68 \%$ of total effective cation exchange capacity. Also, Moya and Pérez (2008) showed that tangential and radial shrinkages were the variables most correlated with soil properties, while the least ones were wood density and volumetric shrinkage. Even though, wood color is an important attribute. It is difficult to find studies relating environmental factors with teak's wood color except for Kokutse et al. (2006), Thulasidas et al. (2006), and Bhat et al. (2005).

Derkyi et al. (2009) found that environmental factors had a stronger effect on teak's heartwood color than the stand age. Also, it was found in some evidence that teak's wood color may be predicted from soil's $\mathrm{pH}$. However, they mentioned that the observed site's range of quality was rather limited. On the other hand, Kokutse et al. $(2010 \mathrm{a}, \mathrm{b})$ found that wood from trees that grew on hydromorphic tropical ferruginous produce lighter wood color; and the redness $a^{*}$ and yellow-blueness $b^{*}$ were significantly higher than in other sites.

Given of the lack of understanding about how environmental factors might affect wood color in plantations, we developed this study with the aim to generate comprehensive information about $T$. grandis' wood color variation from short-rotation forest plantations. The objective is to study the effect of climate characteristics and soil's chemical and physical properties on wood color measured by a CIELab's color system (Gierlinger et al. 2004). With this article, we expect to contribute in the improvement of methodological approach to analyze the effect of environmental factors on wood properties of trees from tropical forest plantations.

\section{Materials and methods}

\subsection{Study area}

A total of 22 forest plots of 7 to 15 years old were selected in the north and northwest regions of Costa Rica covering a 
wide range of soils and climatic conditions. Previous research published by Moya and Berrocal (2010) details geographic coordinates of the different study sites in Table 1. The 22 plots were grouped in five cluster sites that shared similar climatic and soil conditions (Table 1). These cluster sites are identified in this study as: Boca Tapada, Los Chiles, Alemania, Peñas Blancas, and San Francisco. Most of the selected plantation plots corresponded to permanent monitoring growth plots of the collaborating reforestation companies. These plots vary from 300 to $400 \mathrm{~m}^{2}$ (rectangular plots). Very few sampling sites did not have these plots and so circular temporal ones of $11.3-\mathrm{m}$ diameter $\left(400 \mathrm{~m}^{2}\right)$ were established to obtain the basic dasometric information (Moya and Pérez 2008).

\subsection{Environmental characterization}

Data about soil's physical-chemical properties were analyzed from samples taken at $0-20-\mathrm{cm}$ soil depth. In each plot, three soil's sub-samples were gathered and quartered to obtain one $0.5-\mathrm{kg}$ sample for a soil analysis at the Soils and Water Laboratory from the University of Costa Rica. The following information was obtained for each one: $\mathrm{pH}$ in water 1:2; Al (Exchangeable Acidity or Aluminum) by Titration; exchangeable $\mathrm{Ca}$ and $\mathrm{Mg}$ by $\mathrm{KCl} 1 \mathrm{M} 1: 10$ extraction; $\mathrm{P}, \mathrm{K}, \mathrm{Zn}, \mathrm{Fe}, \mathrm{Mn}, \mathrm{Cu}$ by Modified Olsen pH 8.5 1:10 extraction; S, B, N, OM by atomic absorption spectrophotometry; effective cation exchange capacity or ECEC (centimoles of charge per kilogram); clay $(<2 \mu \mathrm{m})$, silt $(<2-50 \mu \mathrm{m})$, and sand $(>50 \mu \mathrm{m})$. Base saturation was estimated from the sum of exchangeable base cations: $(\mathrm{Ca}+\mathrm{Mg}+\mathrm{K} / \mathrm{ECEC} \times 100)$, as the exchangeable acidity saturation: $\mathrm{Al} / \mathrm{ECEC} \times 100$. Three undisturbed core samples (73 mm diameter $\times 64 \mathrm{~mm}$ height) were taken from horizons A at each sampling plot for soil's bulk density measurement (grams per cubic meter) after drying it to $100^{\circ} \mathrm{C}$ for $48 \mathrm{~h}$.

Also, environmental information for each sampling plot using available information from digital maps was collected (ITCR 2004). This information included: plot elevation (meters above sea level (m.a.s.l.)), Holdridge Life Zone,

Table 1 Climatic and edaphic characterization for five cluster sites to study teak wood color in Costa Rica

\begin{tabular}{|c|c|c|c|c|c|c|c|}
\hline \multicolumn{8}{|l|}{ Generalized climatic and soil characterization } \\
\hline \multirow[t]{2}{*}{ Characteristic } & Cluster sites & & & & & & \\
\hline & Boca Tapada & Los Chiles & Alemania & Peñas Blancas & \multicolumn{3}{|l|}{ San Francisco } \\
\hline Mean elevation (m.a.s.l) & 68 & 20 & 274 & 176 & \multicolumn{3}{|l|}{46} \\
\hline Anual temparature in ${ }^{\circ} \mathrm{C}$ & 26 & 27 & 25 & 27 & \multicolumn{3}{|l|}{28} \\
\hline Anual precipitation in $\mathrm{mm}$ & 2,997 & 1,816 & 2,559 & 1,745 & \multicolumn{3}{|l|}{1,594} \\
\hline Annual potential evapotranspiration in $\mathrm{mm}$ & 1,244 & 1,414 & 1,204 & 1,408 & \multicolumn{3}{|l|}{1,639} \\
\hline Actual annual evapotranspiration in $\mathrm{mm}$ & 1,240 & 1,208 & 1,087 & 1,086 & \multicolumn{3}{|l|}{1,106} \\
\hline No dry months & 1 & 3 & 4 & 5 & \multicolumn{3}{|l|}{6} \\
\hline USDA soil order & Ultisols & $\begin{array}{l}\text { Entisols } \\
\text { Inceptisols }\end{array}$ & Ultisols & $\begin{array}{l}\text { Mollisols } \\
\text { Inceptisols }\end{array}$ & \multicolumn{3}{|l|}{$\begin{array}{l}\text { Alfisols } \\
\text { Inceptisols }\end{array}$} \\
\hline Generalized soil texture & Sandy clay loam & Sandy clay loam & Clay & Clay & \multicolumn{3}{|l|}{ Clay loam } \\
\hline Average tree height in $\mathrm{m}$ & 18.9 & 17.8 & 16.7 & 17.8 & \multicolumn{3}{|l|}{22.7} \\
\hline Average tree diameter in $\mathrm{cm}$ & 19.9 & 22.4 & 20.4 & 22.2 & \multicolumn{3}{|l|}{25.1} \\
\hline Average tree density trees $\mathrm{ha}^{-1}$ & 295 & 219 & 425 & 413 & \multicolumn{3}{|l|}{250} \\
\hline \multicolumn{8}{|l|}{ Generalized soil fertility characterization } \\
\hline Cluster sites & pH en $\mathrm{H} 20$ & $\begin{array}{l}\mathrm{Al} \\
\mathrm{cmol}(+) / \mathrm{L}\end{array}$ & $\mathrm{Ca}$ & $\mathrm{Mg}$ & $\mathrm{K}$ & ECEC & Sum of bases \\
\hline Boca Tapada & $5.4 \mathrm{~L}$ & $0.2 \mathrm{~L}$ & $8.0 \mathrm{M}$ & $2.7 \mathrm{M}$ & $0.3 \mathrm{M}$ & $11.2 \mathrm{M}$ & $11.0 \mathrm{M}$ \\
\hline Los Chiles & $4.7 \mathrm{~L}$ & $0.8 \mathrm{M}$ & $4.5 \mathrm{M}$ & $2.5 \mathrm{M}$ & $0.1 \mathrm{~L}$ & $7.9 \mathrm{M}$ & $7.1 \mathrm{~L}$ \\
\hline Alemania & $5.6 \mathrm{M}$ & $0.1 \mathrm{~L}$ & $10.6 \mathrm{M}$ & $2.2 \mathrm{M}$ & $0.3 \mathrm{M}$ & $13.3 \mathrm{M}$ & $13.1 \mathrm{M}$ \\
\hline Peñas Blancas & $5.1 \mathrm{~L}$ & $0.2 \mathrm{~L}$ & $25.3 \mathrm{H}$ & $8.2 \mathrm{H}$ & $0.3 \mathrm{M}$ & $34.0 \mathrm{H}$ & $33.9 \mathrm{M}$ \\
\hline San Francisco & $5.7 \mathrm{M}$ & $0.2 \mathrm{~L}$ & $17.7 \mathrm{M}$ & $8.4 \mathrm{H}$ & $0.2 \mathrm{M}$ & $26.5 \mathrm{H}$ & $26.3 \mathrm{M}$ \\
\hline Cluster sites & $\mathrm{AS}(\%)$ & $\mathrm{P}$ & $\mathrm{Zn}$ & $\mathrm{Cu}$ & $\mathrm{Fe}$ & $\mathrm{Mn}$ & Generalized fertility level \\
\hline Boca Tapada & $1.4 \mathrm{~L}$ & $6.1 \mathrm{~L}$ & $2.8 \mathrm{M}$ & $9.8 \mathrm{M}$ & $224.8 \mathrm{H}$ & $33.1 \mathrm{M}$ & Alta \\
\hline Los Chiles & $10.0 \mathrm{M}$ & $7.3 \mathrm{~L}$ & $2.5 \mathrm{M}$ & $8.0 \mathrm{M}$ & $275.3 \mathrm{M}$ & $80.3 \mathrm{M}$ & Media \\
\hline Alemania & $1.0 \mathrm{~L}$ & $4.5 \mathrm{~L}$ & $4.7 \mathrm{M}$ & $17.5 \mathrm{M}$ & $149.2 \mathrm{H}$ & $46.5 \mathrm{M}$ & Alta \\
\hline Peñas Blancas & $0.5 \mathrm{~L}$ & $2.5 \mathrm{~L}$ & $4.6 \mathrm{M}$ & $6.2 \mathrm{M}$ & $61.1 \mathrm{M}$ & $34.0 \mathrm{M}$ & Alta \\
\hline San Francisco & $0.6 \mathrm{~L}$ & $2.7 \mathrm{~L}$ & $3.0 \mathrm{M}$ & $13.3 \mathrm{M}$ & $85.6 \mathrm{M}$ & $18.0 \mathrm{M}$ & Alta \\
\hline
\end{tabular}

Al aluminum, $C a$ calcium, $M g$ magnesium, $K$ potasium, ECEC Efective Catium Exchange Capacity, $A S$ aluminun saturation, $P$ phosphurus, $C u$ copper, $\mathrm{Fe}$ iron, $M n$ manganese, $Z n$ zinc, $S$ sulfur

Soil fertility and soil nutrients concentration classified: $H$ high, $M$ medium, $L$ low (Bertsch 1995 and 1986) 
and soil type (USA Soil Taxonomy nomenclature). Each variable was obtained by interpolation using GIS. A GPS was used to obtain the coordinates from each plot (Magellan GPS $315^{\mathrm{TM}}$ ). Using data from the nearest meteorological stations, the monthly and annual rainfall and temperature average were estimated for each sample plot. Because few of Costa Rica's meteorological stations register temperatures, regional representative meteorological stations were used to estimate the plot's temperature data: San Carlos (Boca Tapada), Los Chiles (Los Chiles), Upala (Alemania), Liberia (Peñas Blancas), and Nicoya (San Francisco). To adjust the selected temperature station of each plot, a temperature vertical gradient of $0.6^{\circ} \mathrm{C}$ per $100 \mathrm{~m}$ and the elevation difference between each plot were used. All meteorological data came from data bases with at least 10 years of records.

Monthly soil water balance for each plot was estimated according to the Thornthwaite and Mather (1957) method. To use this method, plot data for monthly and annual temperature, rainfall and plot latitude, soil water holding capacity was prearranged. Plot soil water capacity was estimated according to the soil texture and its effective depth. As a result, the estimated monthly soil water balance generated information about annual potential evapotranspiration, actual evapotranspiration, soil water deficit, and water excess. Also, mean annual Holdridge potential evapotranspiration was estimated using the equation $(\mathrm{EVPT}=$ Annual Biotemperature $\times 0.58)$ as well as the relation of the potential evapotranspiration $(\mathrm{RE}=$ Annual precipitation/Annual potential evapotraspiration); all according to Holdridge (1967) and by assuming mean annual temperature as equal to the Holdridge annual biotemperature.

\subsection{Trees and wood samples}

A total of three representative trees next to each plot $(22$ sites $\times 3$ trees $=66$ trees) were harvested. A log of $60 \mathrm{~cm}$ long at a diameter breast height was obtained per tree (66 logs in total) for a laboratory analysis at the Instituto Tecnológico de Costa Rica (ITCR). In this study, a representative tree was considered as one with: a comparable plot mean tree diameter, straight bole, normal branching, and absence of pests or diseases. North orientation was marked on each tree prior the harvesting. Then, it was marked on each log and cross-sectional sample. Each sampled log was sawn into radial boards of $3-\mathrm{cm}$ width through the pith from north to south, labeled $\mathrm{N}$ and $\mathrm{S}$, respectively. These samples were conditioned at $22^{\circ} \mathrm{C}$ and $60 \%$ relative humidity for several weeks until they reached $11-12 \%$ moisture content. Subsequently, all radial boards were re-sawn in 2.5 -cm-thick battens tangential $(3 \times 2.5 \times 60 \mathrm{~cm})$ from pith to bark (Fig. 1). Each small sample was labeled according to sapwood, heartwood, and radial position in the stem, with the
Fig. 1 Sawing pattern use for each stem section to obtain specimens for wood color

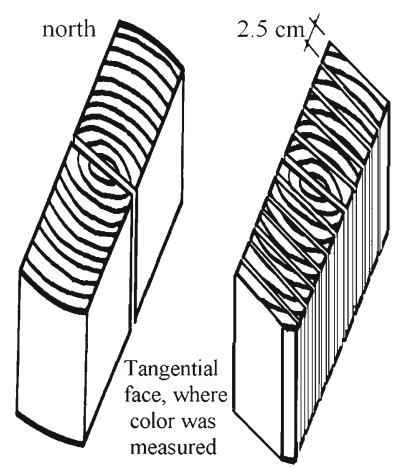

relative distance to the pith. Tangential surfaces were sanded to minimize the risk of wood color values variation for final board consumers. After 2 days of sanding surface, the wood color was measured on tangential surfaces. This is so because it is the typical boards' grain obtained from small logs from Costa Rica's Plantations. (Moya and Pérez 2007).

\subsection{Wood color measurement}

Wood color was measured using a Miniscan XE plus colorimeter (Hunterlab 1995) under temperature and humidity room conditions at the Wood Properties Laboratory in the ITCR ( \pm 2 in temperature). The colorimeter was calibrated each time it was used using a white standard reference supplied by the company. The reflectance spectra were recorded according to the standardized CIELab's chromaticity system as a function of a wavelength (BYK-Gardner 2004). The measurement was set within the visible range of $400-700 \mathrm{~nm}$ at intervals of $10 \mathrm{~nm}$ with a measuring aperture of $11 \mathrm{~mm}$. For the reflection reading, the observer component was set at an angle of $10^{\circ}$ to the sample's normal surface. The light source D65 (corresponding to daylight at $6,500 \mathrm{~K}$ ) was used as a color space measuring and computing parameter. According to HUNTERLAB (1995), the CIELab's color system estimates the wood color in three coordinates: $L^{*}$ for lightness that represents the position on the black-white axis ( $L=0$ for black, $L=100$ for white), $a^{*}$ for chroma value that defines the position on the red-green axis ( +100 values for red, -100 values for green), and $b^{*}$ for chroma value that defines the position of the yellow-blue axis $(+100$ values for yellow, -100 values for blues). The colorimeter was placed on each of the two sample tangential surfaces. Then, two measurements were taken at each point to obtain the average values for the $L^{*}, a^{*}$, and $b^{*}$ coordinates.

Wood color difference index $\Delta E^{*}$, described by Keey (2005), was used to compare wood color parameters between heartwood and sapwood and among sites. This index defines the wood color difference magnitude between two sites using CIELab's color coordinates according to Eq. 1. 
This index was calculated using the average color values for all heartwood and sapwood samples from each site.

$$
\Delta E *=\sqrt{(\Delta L *)^{2}+(\Delta a *)^{2}+(\Delta b *)^{2}}
$$

Where:

$$
\begin{aligned}
& \Delta L^{*}=L^{* M}-L^{* P} \\
& \Delta a^{*}=a^{* M}-a^{* P} \\
& \Delta b^{*}=b^{* M}-b^{* P} \\
& M=\text { Average value for site } 1 \\
& P=\text { Average value for site } 2
\end{aligned}
$$

\subsection{Statistical analysis}

The SAS (SAS Institute Inc.) program was used to conduct the statistical analysis. Normality and presence of extreme data or outliers for each color parameter and environmental characteristic was checked using PROC UNIVARIATE (SAS). Pearson correlation matrixes for sapwood and heartwood were obtained to study the relationship of $L^{*}, a^{*}$, and $b^{*}$ (dependent variables) with environmental parameters (independent variables). The statistical significance was fixed at $P<0.05$. Each significant correlation was examined graphically by plotting the two correlated variables to determine the validity of the relationship. If the plot revealed that the significance of the correlation was from the influence of outliers, it was discarded. The difference of $\Delta E^{*}$ among sites was established by using the mean standard error between two average site difference (Eq. 2), the $t$ valor was calculated with the degrees of freedom using the sum of $n$ samples.

$\left.S_{x 1-x 2}=\sqrt{\frac{\sum X_{1}^{2}+\sum X_{2}^{2}}{n_{1}+n_{2}-2}\left(\frac{1}{n_{1}}\right.}+\frac{1}{n_{2}}\right)$

Where:

$S_{x 1-x 2} \quad$ Mean error standard

$\sum X_{1}^{2} \quad$ Sum square of site 1

$\sum X_{2}^{2} \quad$ Sum square of site 2

$N_{1} \quad$ Samples of site 1

$\mathrm{N}_{2} \quad$ Samples of site 2

Finally, a principal component multivariate analysis was used between color coordinates in heartwood and environmental variables (soil properties and climate characteristics). Principal component analysis is appropriate when you have obtained measures on a number of observed variables and wish to develop a smaller number of artificial ones (called principal components) that will account for most of the variance in the observed variables. The principal components may then be used as predictor or criterion variables in subsequent analyses (Johnson and Wichern 1992). Also, they established two principal components, but the principal component number 2 was only related with wood color parameter. So on this component, all scores of each observation were generated and they were used to establish the model color variation for forward stepwise analysis.

\section{Results}

\subsection{Sample plantations}

The average stand characteristics for all the 22 plots were: 330 trees per hectare with a range of 151 to 580 for tree density; $22 \mathrm{~cm}$ with a range of 15 to $27 \mathrm{~cm}$ for diameter at breast height; and $19 \mathrm{~m}$ with a range of 13 to $26 \mathrm{~m}$ for tree height. All of these depending on the plantation age, management, and site conditions. For more detailed stand description, see Moya and Pérez (2008) and Table 1 for clusters characterization.

\subsection{Climatic and edaphic characterization}

The five cluster sites represent an environmental gradient that includes almost the entire range of climatic and edaphic conditions where Costa Rica's teak is planted. Specific climatic and edaphic data for each plot is not presented here because of space, but in general terms most of the plots data are representative of its site averages. Table 1 summarized the cluster site average conditions and it can be observed that these cluster sites ranged from (1) very wet climates (Boca Tapada) with almost 3,000 $\mathrm{mm}$ of annual precipitation, only one dry month and almost zero soil water deficit to (2) very dry climates (San Francisco) with 1,594 $\mathrm{mm}$ of precipitation, 6 months of dry season, and the highest soil water deficit of $530 \mathrm{~mm}$.

\subsection{Wood color characterization}

The lightness index $\left(L^{*}\right)$ for all tree samples $(n=66)$ ranged for sapwood and heartwood from 80.9 to 63.6 and from 46.8 to 70.6 , respectively; the redness index $\left(a^{*}\right)$ ranged from 1.9 to 11.7 and from 5.1 to 13.6 ; and yellowness $\left(b^{*}\right)$ from 19.4 to 32.6 and from 4.1 to 29.5 , respectively. $L^{*}$ values for sapwood is presented from the higher to the lower value in contrast with the other variables which are from the lower to the higher value. Table 2 summarizes the average color values according to the cluster sites for sapwood and heartwood. This table also includes the pooled average and standard deviation for all samples.

Table 3 includes a matrix comparing the color difference index $\Delta E^{*}$ among sites. From this table, it can be observed that San Francisco site's wood color resulted different from the other ones in both heartwood and sapwood. San Francisco 
Table 2 Summary of wood color parameters according to the CIELab system for T. grandis growing for five cluster sites in Costa Rica $(N=66)$
Notes: The values in parentheses are coefficient of variation

${ }^{\text {a }}$ Wood color difference $\left(\Delta E^{*}\right)$ between heartwood and sapwood

\begin{tabular}{lllll}
\hline \multicolumn{4}{l}{ Heartwood average color values } & \\
Cluster site & $L^{*}$ (lightness) & $a^{*}$ (redness) & $b^{*}$ (yellowness) & $\Delta E^{* \mathrm{a}}$ \\
Boca Tapada & $60.0(8.7)$ & $9.9(11.3)$ & $24.6(3.1)$ & 15.3 \\
Los Chiles & $58.3(9.0)$ & $10.1(13.0)$ & $24.1(1.5)$ & 13.6 \\
Alemania & $59.7(5.3)$ & $10.7(5.8)$ & $25.5(6.3)$ & 14.9 \\
Peñas Blancas & $59.4(6.0)$ & $10.4(9.0)$ & $24.7(2.8)$ & 14.6 \\
San Francisco & $58.5(5.2)$ & $10.4(8.4)$ & $27.7(3.6)$ & 14.1 \\
Average & 59.1 & 10.4 & 25.7 & 14.5 \\
Standard deviation & 4.2 & 1.0 & 1.6 & 4.6 \\
Coefficient of variation & 7.0 & 10.0 & 6.1 & 32.0 \\
& Sapwood average color values & & - \\
Cluster site & $L^{*}$ & $a^{*}$ & $b^{*}$ & - \\
Boca Tapada & $74.2(2.9)$ & $5.8(23.8)$ & 25.0 & - \\
Los Chiles & $74.3(4.4)$ & $5.4(29.6)$ & 26.5 & - \\
Alemania & $74.4(3.0)$ & $5.8(18.2)$ & 25.7 & - \\
Peñas Blancas & $74.2(3.7)$ & $5.0(17.1)$ & 24.6 & - \\
San Francisco & $72.1(3.9)$ & $6.6(14.9)$ & 24.5 & - \\
Average & 73.8 & 5.8 & 25.2 & - \\
Standard deviation & 3.5 & 1.8 & 3.0 & - \\
Coefficient of variation & 4.7 & 31.7 & 11.7 & \\
\hline
\end{tabular}

3.5 Multivariate analysis by principal component and statistical model

The model of principal component between wood color (sapwood or heartwood) and edaphic or environmental variables established two main principal components with high degree of explanation of over $89 \%$ (Table 5). The first component explained the $59.02 \%$ of the variability, and the second one explained the $31.67 \%$ in heartwood color. Meanwhile, the first and second component explained 50.87 and $37.48 \%$ of the total variation in sapwood, respectively (Table 5). The principal component 1 of sapwood, as well as of heartwood, is related with $L^{*}$ and $a^{*}$ color parameters. However, these are not related to any environmental or
Table 3 Total wood color differences $\Delta E^{*}$ obtained by comparing five clusters sites of $T$. grandis in Costa Rica

$n s$ no significant difference

${ }^{a}$ Statistically significant at $95 \%$ confidence

\begin{tabular}{|c|c|c|c|c|c|}
\hline \multirow[b]{2}{*}{ Cluster site } & \multicolumn{5}{|c|}{ Heartwood average color values } \\
\hline & Boca Tapada & Los Chiles & Alemania & Peñas Blancas & San Francisco \\
\hline Boca Tapada & \multicolumn{5}{|l|}{0} \\
\hline Los Chiles & $1.80 \mathrm{~ns}$ & \multicolumn{4}{|l|}{0} \\
\hline Alemania & $1.24 \mathrm{~ns}$ & $2.08 \mathrm{~ns}$ & \multicolumn{3}{|l|}{0} \\
\hline Peñas Blancas & $0.79 \mathrm{~ns}$ & $1.30 \mathrm{~ns}$ & $0.91 \mathrm{~ns}$ & 0 & \\
\hline \multirow[t]{2}{*}{ San Francisco } & $3.48^{\mathrm{a}}$ & $3.62^{\mathrm{a}}$ & $2.52^{\mathrm{a}}$ & $3.1^{\mathrm{a}}$ & 0 \\
\hline & \multicolumn{5}{|c|}{ Sapwood average color values } \\
\hline Cluster site & Boca Tapada & Los Chiles & Alemania & Peñas Blancas & San Francisco \\
\hline Boca Tapada & 0 & & & & \\
\hline Los Chiles & $1.56 \mathrm{~ns}$ & 0 & & & \\
\hline Alemania & $0.73 \mathrm{~ns}$ & $0.90 \mathrm{~ns}$ & 0 & & \\
\hline Peñas Blancas & $0.89 \mathrm{~ns}$ & $1.94 \mathrm{~ns}$ & $1.37 \mathrm{~ns}$ & 0 & \\
\hline San Francisco & $2.30^{\mathrm{a}}$ & $3.21^{\mathrm{a}}$ & $2.71^{\mathrm{a}}$ & $2.64^{\mathrm{a}}$ & 0 \\
\hline
\end{tabular}




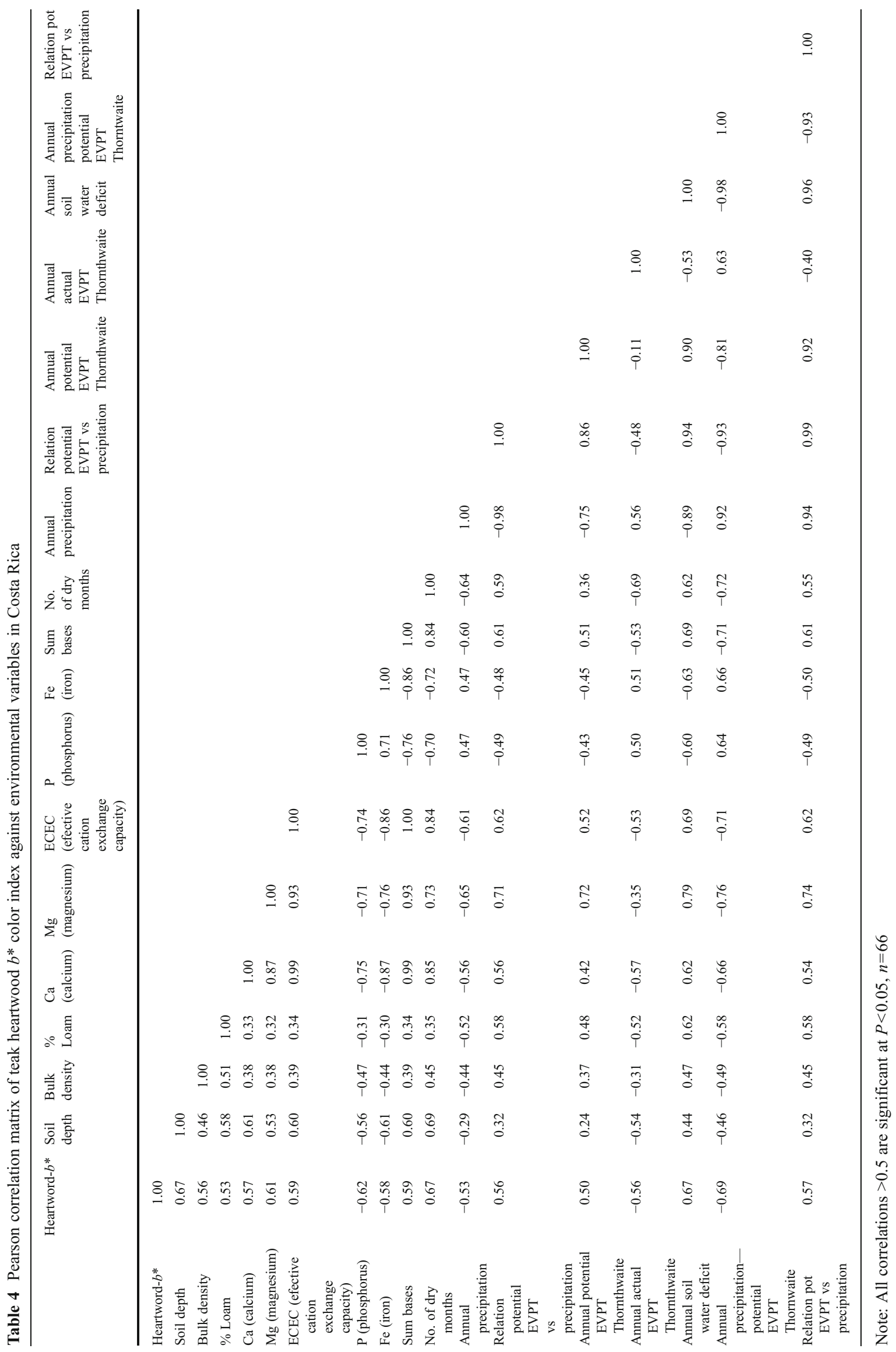


Table 5 Statistical parameters of principal components from environmental variables and wood color parameters in heartwood and sapwood in $T$. grandis trees growing in Costa Rica $(N=66)$

\begin{tabular}{|c|c|c|c|c|c|c|}
\hline \multirow[t]{2}{*}{ Parameters } & \multicolumn{3}{|c|}{ Principal component of heartwood } & \multicolumn{3}{|c|}{ Principal component of sapwood } \\
\hline & 1 & 2 & 3 & 1 & 2 & 3 \\
\hline Eigenvalue & 1.77 & 0.95 & 0.28 & 1.53 & 1.12 & 0.35 \\
\hline$\%$ Total of variance & 59.02 & 31.67 & 9.31 & 50.87 & 37.48 & 11.66 \\
\hline Cumulative eigen value & 1.77 & 2.72 & 3.00 & 1.53 & 2.65 & 3.00 \\
\hline Total cumulative & 59.02 & 90.69 & 100.00 & 50.87 & 88.34 & 100.00 \\
\hline
\end{tabular}

edaphic variable. Tree age was only correlated with principal component 1 in heartwood (Table 6). In the meantime, $b^{*}$ color parameter in heartwood was corrected with principal component 2 , and it was correlated statistically $(\alpha<0.05)$ with several environmental and edaphic variables (Table 6). No correlation was found between environmental or edaphic variables and this component in sapwood.

The stepwise multiple regression applied on scores of principal component 2 of heartwood (interpreted as heartwood's yellowness color) showed that the difference of these parameters are attributed to variation of two soil and three environmental variables, explaining the $70 \%$ of the principal component 2's discrepancy (Table 7). However, the relation of potential evapotranspiration (annual precipitation/annual potential evapotranspiration), soil depth, and bulk density were statistically correlated with this component (Table 7). They explained 47, 16 and $5 \%$, respectively, the variation of principal component 2 . According to these results, the score differences were modeled (interpreted by the yellow tonalities of heartwood color) with these five variables (Eq. 3); and it was found that all variables affected positively the score values.

Model

$$
\beta^{*}=0.131 \beta_{1}+0.321 \beta_{2}+0.247 \beta_{3}+0.165 \beta_{4}+0.821 \beta_{5}
$$

Where

$\beta_{1}$ Monthly precipitation-potential Thornthwaite evapotranspiration

$\beta_{2}$ Soil depth

$\beta_{3}$ Bulk density

$\beta_{4}$ Mean annual soil water deficit (millimeters)

$\beta_{5}$ Relation potential evapotranspiration vs precipitation (Thornthwaite)

\section{Discussion}

\subsection{Climatic and edaphic characterization}

In terms of soil, these sites cover a wide range of chemical and physical properties (Table 1). They included ultisols that represent the most infertile and acid conditions to mollisols, the best soils for agriculture because of its high concentration of bases and low acidity. As it can be observed in Table 1, there is a close relationship between climatic and soil fertility characteristics; dry climates are associated with best fertility levels, and wet climates with poor fertility levels. This relationship can be explained by recognizing two principal soils forming processes: soil erosion and base lixiviation, processes that are accentuated in wet climates reducing the soil fertility and increasing the soil acidification (Sánchez 1976; Buol et al. 1980). This observation is confirmed by relating the sum of bases $(\mathrm{Ca}+\mathrm{Mg}+\mathrm{K})$ or the ECEC with annual rainfall, soil water deficit, or length of dry season.

\subsection{Wood color characterization}

It can be seen from Table 2 that values in wood color coordinates are positive, so the color composition for Costa Rica's Teak can be classified as dark $\left(L^{*}>46.8\right)$, red, and yellow tones $\left(0<a^{*}<13.6\right.$ and $\left.4.1<b^{*}<32.6\right)$. It also can be noticed that the sample standards of $L^{*}$ and $b^{*}$ of sapwood and $L^{*}, a^{*}$, and $b^{*}$ of the heartwood's values had a small variation (coefficients of variation $<11.7 \%$ ). On the other hand, the $a^{*}$ sapwood's values had the largest differentiation (coefficient variation $>31 \%$ ), which implies that redness varies strongly among sites. As expected, the wood color composition of heartwood and sapwood were different. Heartwood color has comparably lower values of $L^{*}$ and higher values of $a^{*}$ in relation to sapwood. Both comparisons presented were significant statistical difference at $P<0.05$. The change in color between sapwood and heartwood is due to the heartwood formation, where oxidation and polymerization of phenolic components are presented (Burtin et al. 1998; Gierlinger et al. 2004).

The wood color difference index $\Delta E^{*}$ (Eq. 1, Tables 2 and 3 ) is expressed as a distance between two points in the color coordinate system, a quadratic addition of each coordinate difference (Gonnet 1993). Cui et al. (2004) mentioned that the color's change value $\left(\Delta E^{*}\right)$ defined the levels that are perceive the color's difference. $\Delta E^{*}$ varying for 0 to 0.5 is defined as negligible, between 0.5 and 1.5 is slightly perceivable, from 1.5 to 3.0 is noticeable, from 3.0 to 6.0 is appreciable, and from 6.0 to 12.0 is very appreciable. Consequently, for this study a value higher than 1.5 units in Teak's wood color difference index $\left(\Delta E^{*}\right)$, from two 
sampled sites, will produce a distinction noticeable or appreciable in visual perception. According with $\Delta E^{*}$ and $L^{*}$, $a^{*}$, and $b^{*}$ values (Table 3 ), the sapwood or heartwood's wood color difference can be easily visualized and distinguished between the San Francisco cluster site and the other four cluster ones. Hence, heartwood produced from trees from San Francisco has a more yellowish-brown color than the other cluster sites, as a result of lower $L^{*}$ and higher $b^{*}$ values (Table 3). Also, it was observed that San Francisco cluster sites' wood color is more similar to the one described by Bhat (1999) for dry climates of Central Asia.

By comparing wood color difference index $\Delta E^{*}$ (Gonnet 1993) among five cluster sites, San Francisco ones resulted with different wood color both in heartwood and sapwood. Consequently, heartwood produced from trees from drier and fertile sites, as San Francisco, has a more yellowishbrown color, similar to the one described by Bhat (1999) for the dry climates of Central Asia. Hence, sites from the

Table 6 Correlations between different principal component and wood color parameters and environmental variables in $T$. grandis trees growing in Costa Rica $(N=66)$

\begin{tabular}{|c|c|c|c|c|c|c|}
\hline \multirow[t]{2}{*}{ Parameters } & \multicolumn{3}{|c|}{ Principal component of sapwood } & \multicolumn{3}{|c|}{ Principal component of heartwood } \\
\hline & 1 & 2 & 3 & 1 & 2 & 3 \\
\hline$L^{*}$ & $0.86^{* *}$ & -0.33 & 0.38 & $-0.91 * *$ & 0.18 & 0.37 \\
\hline$a^{*}$ & $-0.88 * *$ & -0.27 & 0.39 & $0.91 * *$ & -0.16 & 0.37 \\
\hline$b^{*}$ & 0.04 & $0.97 * *$ & 0.24 & 0.33 & $0.94 * *$ & -0.01 \\
\hline Tree age & -0.30 & 0.05 & 0.32 & $0.53 * *$ & 0.08 & -0.19 \\
\hline Soil depth & -0.18 & -0.23 & -0.18 & 0.28 & $0.62 * *$ & 0.03 \\
\hline Soil water deficit & -0.13 & 0.04 & 0.30 & -0.01 & $-0.52 * *$ & -0.26 \\
\hline Bulk density & -0.08 & 0.00 & -0.14 & 0.14 & $0.55^{* *}$ & 0.03 \\
\hline$\%$ Loam & 0.03 & -0.05 & -0.11 & 0.01 & 0.09 & 0.17 \\
\hline$\%$ Clay & -0.10 & -0.03 & -0.03 & 0.09 & $0.53 * *$ & -0.04 \\
\hline$\%$ Sand & 0.02 & 0.07 & 0.14 & -0.06 & -0.39 & -0.17 \\
\hline $\mathrm{pH}$ & -0.05 & 0.03 & 0.23 & 0.03 & 0.12 & 0.03 \\
\hline $\mathrm{Ca}$ & 0.09 & -0.08 & -0.33 & 0.16 & $0.54 * *$ & -0.05 \\
\hline $\mathrm{Mg}$ & -0.06 & -0.13 & -0.39 & 0.16 & $0.58 * *$ & -0.14 \\
\hline $\mathrm{K}$ & 0.00 & -0.04 & 0.04 & -0.05 & 0.22 & 0.00 \\
\hline ECEC & 0.05 & -0.10 & -0.36 & 0.16 & $0.57 * *$ & -0.08 \\
\hline Base saturation & -0.07 & 0.01 & 0.07 & -0.35 & -0.24 & -0.10 \\
\hline $\mathrm{P}$ & 0.03 & 0.00 & 0.23 & -0.33 & $-0.54 * *$ & -0.07 \\
\hline $\mathrm{Zn}$ & 0.05 & -0.27 & -0.06 & 0.12 & 0.18 & 0.15 \\
\hline $\mathrm{Cu}$ & -0.17 & -0.09 & 0.33 & 0.17 & 0.07 & 0.11 \\
\hline $\mathrm{Fe}$ & 0.02 & 0.06 & 0.26 & -0.11 & $-0.57 * *$ & 0.00 \\
\hline $\mathrm{Mn}$ & 0.04 & 0.03 & 0.05 & -0.16 & -0.28 & 0.01 \\
\hline No. of dry months (map) & 0.07 & -0.11 & -0.31 & 0.27 & $0.61 * *$ & 0.03 \\
\hline Mean annual temperature & -0.19 & -0.12 & -0.12 & 0.12 & 0.48 & -0.17 \\
\hline Elevation & 0.01 & 0.12 & -0.03 & 0.15 & 0.21 & 0.28 \\
\hline Mean annual precipitation & 0.03 & -0.01 & 0.16 & -0.28 & -0.46 & 0.01 \\
\hline Potential annual evapotranspiration Holdridge & -0.19 & -0.12 & -0.12 & 0.12 & 0.48 & -0.17 \\
\hline Relation potential evapotranspiration vs precipitation & -0.08 & -0.03 & -0.17 & 0.25 & $0.51 * *$ & -0.07 \\
\hline Mean annual potential evapotranspiration Thornthwaite & -0.20 & -0.12 & -0.15 & 0.12 & 0.49 & -0.16 \\
\hline Mean annual actual evapotranspiration Thornthwaite & 0.03 & -0.01 & 0.10 & -0.28 & $-0.50 * *$ & -0.21 \\
\hline Mean annual soil water deficit & -0.18 & -0.09 & -0.19 & 0.22 & $0.64 * *$ & -0.04 \\
\hline Monthly precipitation - potential Thornthwaite evapotranspiration & 0.12 & 0.06 & 0.18 & -0.27 & $-0.63 * *$ & -0.03 \\
\hline Relation actual evapotranspiration vs precipitation & -0.05 & 0.00 & -0.16 & 0.22 & 0.38 & -0.10 \\
\hline Relation potential evapotranspiration vs precipitation & -0.12 & -0.06 & -0.17 & 0.22 & $0.52 * *$ & -0.09 \\
\hline Sum bases & 0.05 & -0.09 & -0.35 & 0.17 & $0.57 * *$ & -0.08 \\
\hline$\%$ Bases & 0.07 & -0.01 & -0.07 & 0.35 & 0.24 & 0.10 \\
\hline
\end{tabular}

${ }^{*} p<0.05 ; * * p<0.01$, statistically significant 
Table 7 Multiple correlation analysis for the relationship between scores of principal component 2 and soil properties of $T$. grandis plantations in Costa Rica

$N S$ not significant

${ }^{*} p<0.05$, statistically significant

\begin{tabular}{lllll}
\hline Variable & Step & $\begin{array}{l}\text { Multiple } \\
\text { correlation } \\
\text { coefficient }\left(r^{2}\right)\end{array}$ & $\begin{array}{l}\text { Multiple } \\
\text { correlation } \\
\text { coefficient }\left(r^{2}\right)\end{array}$ & $F$ value \\
\hline $\begin{array}{l}\text { Monthly precipitation - potential Thornthwaite } \\
\text { evapotranspiration }\end{array}$ & 1 & 0.47 & 0.47 & $55.90^{*}$ \\
$\begin{array}{l}\text { Soil depth } \\
\text { Bulk density }\end{array}$ & 2 & 0.63 & 0.16 & $27.83^{*}$ \\
$\begin{array}{l}\text { Mean annual soil water deficit } \\
\begin{array}{l}\text { Relation potential evapotranspiration vs } \\
\text { precipitation (Thornthwaite) }\end{array}\end{array}$ & 3 & 0.68 & 0.05 & $8.96^{*}$ \\
\hline
\end{tabular}

Peninsula de Nicoya in Costa Rica would tend to produce darker teak heartwood color (brown color) that other study sites (light color), while sapwood color is less yellow than other places.

\subsection{Pearson correlations of wood color parameters} with environmental factors

Only heartwood $b^{*}$ color index resulted in significant correlations $(R>0.5, P<0.05, n=66)$ with environmental variables in 22 sites (Table 4). That is, heartwood $L^{*}$ and $a^{*}$ and sapwood $L^{*}, a^{*}$, and $b^{*}$ wood color indices were not related to any environmental variables. This implies that only heartwood $b^{*}$ or chroma value for the yellow-blue axis is affected by environmental variables. These findings are also supported by Thulasidas et al. (2006) results, although they did not study the relationship of soil properties and wood color in T. grandis. They measured the heartwood color variation between a wet and dry sites from Kerala (India); and found that only the yellowness index $\left(b^{*}\right)$ was statistically different. These authors hypothesized that yellowness index $\left(b^{*}\right)$ is more affected by environmental factors than $L^{*}$ and $a^{*}$ color indices. According with Gierlinger et al. (2004), redness $\left(a^{*}\right)$ and lightness $\left(L^{*}\right)$ index are more correlated with wood extractive content, while yellowness index is primarily related to the lignin's photochemistry. This explains why soil properties affected mainly chemical components of $T$. grandis' wood. However, extractives content were not affected and so, redness $\left(a^{*}\right)$ and lightness $\left(L^{*}\right)$ were not disturbed by soil properties.

Either edaphic or climatic variables could be used to explain the variation of $b^{*}$ color almost equivalently (Table 4). Nevertheless, caution must be taken when deciding if the relationship is causal or accidental. This is important since knowing the true causal factors that affect wood color is a key to recommend either management practices or site selection criteria for teak's plantation. An inspection of this table reveals that edaphic and climatic variables are also self-correlated, which causes a co-linearity problem (Rawlings 1988). In this case it is important to study the causes of this co-linearity in order to decide which variables are truly causal.

According to Buol et al. (1980) soil properties are a function of climate, parent material, vegetation, and time. Hence, climate is a controlling factor for soil formation and consequently climate variables are first-order causal variables that should explain wood color variation. In this case it is easy to notice that dry climates are associated with deeper and more fertile sites. The less intense effect of soil erosion and cation lixiviation in these climates can explain the reasons of these relationships, as indicated in Section 3.2. It turns out that wood color is better in these edaphic conditions but at the same time these edaphic conditions are the result of the prevailing drier climate. Figure 2 illustrates this discussion, plots a and $\mathrm{b}$ show how ECEC or mean annual soil water deficit (MASWD) are linearly related with heartwood $b^{*}$ color $\left(R^{2}=0.35\right.$ and $R^{2}=0.45$, respectively), but at the same time how these two independent variables are correlated among $\left(R^{2}=0.48\right)$ themselves causing a colinearity problem (Fig. 2c). From Fig. 2, it also can be seen that the best linear relationship of $b^{*}$ is with MASWD, while the relationship with ECEC is not so linear, indicating that soil properties, such as ECEC, might not be necessarily a wood color causal variable.

4.4 Multivariate analysis by principal component and statistical model

The principal component 1 of sapwood, as well as heartwood, is related with $L^{*}$ and $a^{*}$ color parameters, and this component is not related with any environmental or edaphic variable. Tree age was only correlated with principal component 1 in heartwood (Table 6). According to these results, this component can be interpreted by lightness of wood and it describes the relationship of $L^{*}$ and $a^{*}$ parameters. Previous research carried out by Moya and Berrocal (2010) confirms this relationship. They showed the relationships among the color parameters defining the heartwood and sapwood measurements. A significant correlation was found only between $L^{*}$ and $a^{*}$ in both sapwood and heartwood. 

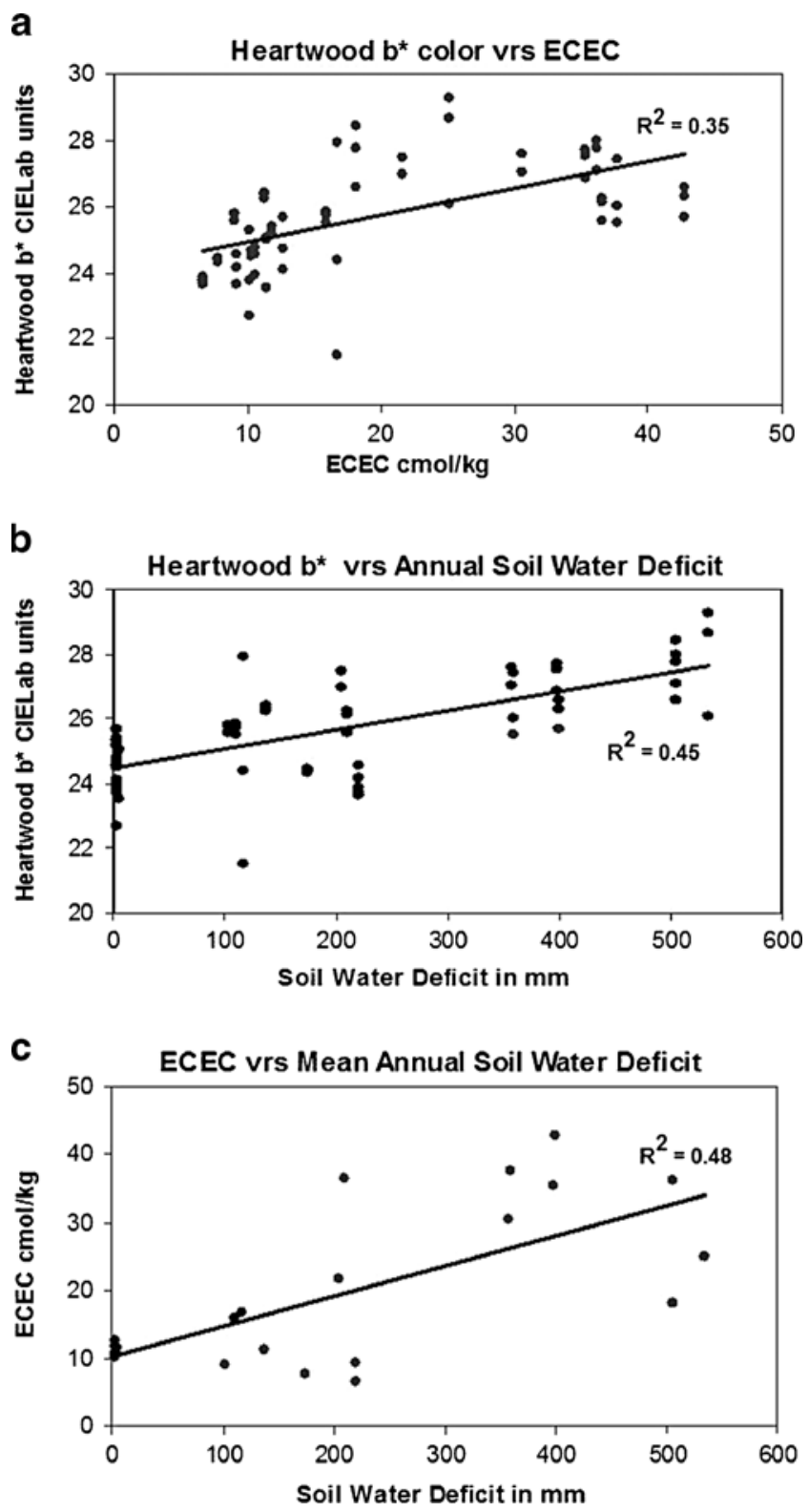

Fig. 2 Relationship of effective cation exchange capacity (ECEC) and mean annual soil water deficit (MASWD) with heartwood $b^{*}$ color (a, b), and relationship of ECEC and MASWD (c) in 22 teak plantations in Costa Rica

These results show that the variation in wood color of $T$. grandis is produced by an inverse variation between $L^{*}$ and $a^{*}$ coordinates, lightness, and redness, respectively.

On the other hand, principal component 2 in sapwood and heartwood was correlated only with $b^{*}$ (Table 6), and these results suggested that this principal component is interpreted as yellowness of wood color in sapwood and heartwood. No correlation was found with environmental or edaphic variables with this component in sapwood. These results confirmed previous Pearson correlation analysis (Table 4), which showed that any color parameters of sapwood was not correlated with environmental or edaphic variables.
Only heartwood $b^{*}$ color index resulted in significant correlations $(R>0.5, P<0.05)$ with nine climatic and eight edaphic variables at 22 sites (Table 6). However, after multivariate and multiple regression analysis, it was found that monthly precipitation - potential Thornthwaite evapotranspiration was the main climatic variable with the highest effect in color parameters (Table 7). Taking into account that climate is a controlling factor of soil formation, it was concluded that climatic variables should be considered as first-order casual variables to explain wood color variation. Thus, darker $b^{*}$ wood color is associated with drier climates that also are related with deeper and fertile sites.

Although, it is difficult to conclude which environmental factor can truly explain wood color variation, it was found that drier climates, independently of edaphic properties, will produce better wood color in T. grandis. Heartwood formation in $T$. grandis is characterized by activation of secondary metabolism with formation of extractives which play a key role in heartwood color (Datta and Kumar 1987). It was considered that extractives in the heartwood (Burtin et al. 1998; Gierlinger et al. 2004) will take place at different rates in drier climates than in humid climates. The extractives or molecules, such as tectoniquinone, naphthoquinone; methanol extractives; and soluble extractives in petroleum-ether, methanol, acetone/water, and ethanol/water presented starch, lipids, and proteins among molecules into wood are different for soil or environmental conditions (Rudman and Da Costa 1959; Datta and Kumar, 1987; Thulasidas and Bhat 2007). The variation of heartwood's color is produced by the content of extractives, therefore by the dynamics of heartwood's formation. These influence the tree's growth rate, crown size and stem size (Kokutse et al. 2010b). If the environmental factors are favorable to the tree growth, the tree will present less extractives, so the wood will be less dark because the reserve material is oriented for the need of the tree rather than the extractives formation. A tree with a slower (due to dry season) growth will present a larger stem diameter (Thulasidas and Bhat 2007) because of the higher dynamics of heartwood's formation, so higher extractives content: a darker wood color (Kokutse et al. 2010b). On the other hand, length of the dry season and magnitude of soil water deficits reduce tree growth during this period. This causes the aging of wood tissues in different wood properties that are usually preferred than wood coming from more humid sites. We also hypothesized that most wood chemical and physical properties for the majority of tree species should also vary primarily according to climatic characteristics rather than with edaphic properties. This hypothesis is also supported by the evidence developed by Thulasidas et al. (2006) and Bhat et al. (2005) who reported light brown teak color from humid sites.

In light of the results and discussion of this study, we question all previous studies (e.g., Maeglin and Nelson 
1970; Moya and Pérez 2008; Cutter et al. 2004) that assigned a causal relationship between any wood properties with edaphic variables if comprehensive climatic and soil water balance variables were not included in the analysis. The strong correlation between edaphic and climatic variables tends to mask the true causal relationship and it might result in erroneous conclusions for management recommendations.

Finally, we recognized that the results discussed in this study are of observational nature and consequently we recommend conducting an experimental study to test our hypothesis and reach definite conclusions about which environmental variables truly explain wood color and other wood properties variation. Such study should provide definitive soil management and site selection criteria for teak's plantations and should become the basis for the design of studies of this nature.

Acknowledgments This project was supported by the Instituto Tecnológico de Costa Rica and by the Centro de Investigación Integración Bosque-Industria de la Escuela Forestal. Special thanks to all teak reforestation companies that collaborated in this study: Precious Woods of Central America (MACORI), Ecodirecta Groups, and Panamericans Woods. Special recognitions to the Vicerectoria de Investigación de Instituto Tecnológico de Costa Rica (ITCR) for their support throughout all the phases of this study.

\section{References}

Alvarado A (2006) Nutrición y fertilización de la teca. Universidad de Costa Rica. Infor Agr 61:1-8

Alvarado A, Fallas JL (2004) La saturación de acidez y el encalado sobre el crecimiento de la teca (Tectona grandis L.f.) en suelos ácidos de Costa Rica. Rev Agr Costarricense 28:81-87

Bermejo I, Cañellas I, San Miguel A (2004) Growth and yield models for teak plantations in Costa Rica. For Ecol Manage 189:97-110

Bertsch F (1986) Manual para interpretar la fertilidad de los suelos de Costa Rica. Editorial Universidad de Costa Rica, San José, Costa Rica

Bertsch F (1995) La Fertilidad de los suelos y su manejo. Asociación Costarricense de la Ciencia del Suelo - UCR, San José, Costa Rica

Bhat KM (1999) Is fast grown teak inferior in wood quality - an appraisal of wood figure (colour, grain, texture) from plantations of high input management. Wood News 9:48-49

Bhat KM, Thulasidas PK, Florence EJL (2005) Wood durability of home-garden teak against brown-rot and white-rot fungi. Trees Struc Funt 9:654-660

Buol S, Hole F, MacCracken R (1980) Soil genesis and classification, 2nd edn. The Iowa State University Press, Ames, Iowa

Burtin P, Jay-Allemand C, Charpentier J, Janin G (1998) Natural wood colouring process in Juglans sp. (J. regia and hybrid J. nigra $23 \mathrm{x}$ $J$. regia) depends on native phenolic compounds accumulated in the transition zone between sapwood and heartwood. Trees Struc Funt 12:258-264

BYK-Gardner (2004) CIE $L^{*} a^{*} b^{*}$ system. Color-guide 45/0 operating instructions, MD, USA.

Cui W, Kamdem P, Rypstra T (2004) Diffuse reflectance infrared fourier transform spectroscopy (DRIFT) and color changes of artificial weathered wood. Wood Fiber Sci 36:291-301
Cutter BE, Coggeshall MV, Phelps JE, Stokke DD (2004) Impacts of forest management activities on selected hardwood wood quality attributes: a review. Wood Fiber Sci 36:84-97

Datta SK, Kumar A (1987) Histochemical studies of the transition from sapwood to heartwood in Tectona grandis. IAWA Bull 8:363-368

Derkyi NSA, Bailleres H, Chaix G, Thevenon MF, Oteng-Amoako AA, Adu-Bredu S (2009) Colour variation in Teak (Tectona grandis) wood from plantations across the ecological zones of Ghana. Ghana J For 25:40-49

FAO (2006) Global planted forest thematic study: results and analysis, by Del Lungo, J.B., Carle, J. Planted Forests and trees: Working paper 38. Rome. Italy.

Gierlinger N, Jacques D, Grabner M, Wimmer R, Schwanninger M, Rozenberg P, Pâques LE (2004) Colour of larch heartwood and relationships to extractives and brown-rot decay resistance. Trees Struc Funt 18:102-108

Gonnet JF (1993) CIELab measurement, a precise communication in flower colour: an example with carnation (Dianthus caryophyllus) cultivars. J Hort Sci 68:499-510

Holdridge L (1967) Life zone ecology. Published by Tropical Science Center, San Jose, Costa Rica, 206 p

HunterLab (1995). The measurement of apparence. In: Richard S, Hunter R, Richard W. Harold (eds). Wiley, New York, pp. 411456.

ITCR (2004) Atlas digital de Costa Rica. Laboratorio de Sistemas de Información geográfica, Escuela de Ingeniería Forestal, Instituto Tecnológico de Costa Rica (ITCR), Cartago, Costa Rica

Johansson D, Morén T (2006) The potential of colour measurement for strength prediction on thermally treated wood. Holz Roh Werkst 64:104-110

Johnson RA, Wichern DW (1992) Applied multivariate statistical analysis. 3rd edn. MacGraw-Hill, New York.

Kamdem DP, Grelier S (2005) Surface roughness and color change of copper-amine treated red maple (Acer rubrum) exposed to artificial ultraviolet light. Holzforschung 56:473-478

Keey RB (2005) Colour development on drying. Maderas: Ciencia Tecnol 7:3-16

Kokutse AD, Stokes A, Baillères H, Kokou K, Baudasse C (2006) Decay resistance of Togolese teak (Tectona grandis) heartwood and relationship with colour. Trees Struc Funt 20:219-223

Kokutse AD, Amusant N, Boutahar N, Chaix G (2010a) Influence of soil properties on the natural durability, extractive content and colour of teak (Tectona grandis L.f) wood in Togo. Annales de l'Université de Parakou: Série Sciences Naturelles et Agronomie $1: 28-29$

Kokutse AD, Stokes A, Kokutse NK, Kokou K (2010b) Which factors most influence heartwood distribution and radial growth in plantation teak? Ann For Sci 67:407-420

Liu S, Loup C, Gril J, Dumonceaud O, Thibaut A, Thibaut B (2005) Studies on European beech (Fagus sylvatica L.). Part 1. Variations of wood color parameters. Ann For Sci 62:625-632

Maeglin RR, Nelson ND (1970) Surface soil properties of black walnut sites in relationship to wood color. Soil Sci Soc Am J 34:142-146

Mazet JF, Janin G (1990) La qualité de l'aspect des placages de Chênes (Quercus petraea and Quercus robur): mesures de couleur et critères de d'appréciation des professionnels français et italiens. Ann For Sci 47:255-268

Möttönen V, Alvila L, Pakkanen TT (2002) CIEL*a*b* measurements to determine the role of felling season, log storage and kiln drying on coloration of silver birch wood. Scand J For Res 17:179-191

Moya R, Berrocal A (2010) Wood colour variation in sapwood and heartwood of young trees of Tectona grandis and its relationship with plantation characteristics, site, and decay resistance. Ann For Sci 67:109

Moya R, Pérez D (2007) Processing and marketing of teakwood products from fast-grown teak plantations in Costa Rica. In: Nair 
K, Bhat KV, Anitha V (eds) Abstracts Products and Marketing of teak wood products of planted forest. Regional Workshop Products and Marketing of teak wood products of planted forest. 2528. September 2007. KFRI, Peechi, India, pp 25-28

Moya R, Pérez D (2008) Effect of physical and chemical soil properties on wood characteristics of Tectona grandis plantations in Costa Rica. J Trop For Sci 20:147-155

Nishino Y, Janin G, Chanson B, Détienne P, Gril J, Thibaut B (1998) Colorimetry of wood specimens from French Guiana. J Wood Sci 44:3-8

Nishino Y, Janin G, Yamada G, Kitano D (2000) Relations between the colometric values and densities of sapwood. J Wood Sci 46:267-272

Pal, M. and Husen, M. 2003. Effect of nitrogen, phosphorous and potassium application to stock plants on nutrient status of coppice shoots of teak (Tectona grandis Linn. f.). Silave Genetica 52: 249-254.

Perez D, Kanninen M (2005) Stand growth scenarios for Tectona grandis plantations in Costa Rica. For Ecol Manage 210:425-441

Phelps JE, McGinnes EJr, Garrett HE, Cox GS (1983) Growth-quality evaluation of black walnut wood. Part II-color analyses of veneer produced on different sites. Wood Fiber Sci 15:177-185

Rawlings J (1988) Applied regression analysis. A research tool. Wadsworth and Brooks/Cole Advanced Books and Software, NY, USA, NY, USA

Rigatto PA, Dedecek RA, Monteiro de Matos JL (2004) Influência dos atributos do solo sobre a qualidade da madeira de Pinus taeda para produção de celulose kraft. Revista árvore 28:267-273

Rink G, Phelps JE (1989) Variation in heartwood and sapwood properties among 10-year-old black walnut trees. Wood Fiber Sci $21: 177-182$

Rudman P, Da Costa WB (1959) Variation in extractive content and decay resistance in the heartwood of Tectona grandis L.f. J Inst Wood Sci 3:33-42
Sánchez P (1976) Properties and management of soils in the tropics. John Wiley and Sons, New York, USA

Saranpää P (2003) Word density and growth. In: Jeronimidis G (ed) Wood quality and its biological basis. Blackwell Publishing Ltd., Oxford, UK

Sotelo-Montes C, Hernández RE, Beaulieu J, Weber J (2008) Genetic variation in wood color and its correlations with tree growth and wood density of Calycophyllum spruceanum at an early age in the Peruvian Amazon. New forest 35:57-73

Tewari DN (1999) A monograph on teak (Tectona grandis). International Book Distrutors. Dehra Dun, India

Thornthwaite CW, Mather JR (1957) Instructions and tables for computing potential evapotranspiration and the water balance. Climatology 10:183-311

Thulasidas PK, Bhat KM (2007) Chemical extractive compounds determining the brown-rot decay resistance of teak wood. Holz Roh Werkst 65:121-124

Thulasidas PK, Bhat KM, Okuma T (2006) Heartwood colour variation in home garden teak (Tectona grandis) from wet and dry localities of Kerala, India. J Trop For Sci 18:51-54

Ugalde L, Alvarado A, Verjans JM, Mollinedo M, Rudy LC (2005) Soil-tree relationship and site factors in young teak (Tectona grandis) plantations in the Western zone of the Panama Canal. Rev Agr Costarricense 28:81-87

Vetter RE, Coradin VR, Martino EC, Camargos J (1990) Wood colour — a comparison between methods. IAWA Bull 11:429-124

Webb MJ, Reddell P, Nath S, Srivastava RJ (2006) Determining P and $\mathrm{N}$ status of a tropical timber species (teak): assessment of 'quick' chemical tests and a root phosphatase assay. Develop Plant Soil Sci 92:706-707

Zobel B, Van Buijtenen B (1989) Wood variation: its causes and control. Springer Verlag, New York. USA 